\title{
Internationalization of Entrepreneurship - Motivating Factors: Case Study of the Slovak Republic
}

\author{
Mariana Dubravská ${ }^{1}$, Ladislav Mura ${ }^{2}$, Rastislav Kotulič ${ }^{1}$, \\ Jaroslav Novotný $\dot{y}^{3}$ \\ ${ }^{1}$ Faculty of Management, University of Prešov in Prešov \\ Konštantínova 16, 08001 Prešov, Slovakia \\ E-mail: mariana.dubravska@unipo.sk; rastislav.kotulic@unipo.sk \\ ${ }^{2}$ Faculty of Economics, J. Selye University in Komárno \\ Bratislavská cesta 3322, 94501 Komárno, Slovakia, E-mail: mural@ selyeuni.sk \\ ${ }^{3}$ Dubnica Institute of Technology in Dubnica nad Váhom \\ Sládkovičova 533/20, 01841 Dubnica nad Váhom, Slovakia \\ E-mail: novotny@dti.sk
}

\begin{abstract}
The goal of this paper is to identify the factors motivating Slovak companies by the internationalization of their business activities. Based on methodology, we have searched the factors influencing specific Slovak companies operating in foreign markets and tested for statistically significant differences among the individual factors that motivate Slovak companies for the internationalization of their business activities. In the majority of factors, the influence was proven by the companies managers. The relationship between the examined factors and the level of foreign trade activities, expressed by foreign sales volume, was tested. Thru the foreign working experience of business management, the relationship was confirmed. At the same time, it is possible to identify that there is no statistically significant difference, among the individual factors, that motivate Slovak companies for the internationalization of their business activities.
\end{abstract}

Keywords: internationalization; business; motivation factors; Slovak Republic

\section{Introduction}

At the beginning of $21^{\text {st }}$ Century, the development of business activities was connected with an enterprises penetration into foreign markets. Internalization offers new opportunities for the enterprise. On one hand, it enables an increase of their income, due to the increasing volume products and services, on the other hand, it enables a decrease of the costs, searching for possibilities in world 
markets and the possibilities of the resource optimization in enterprises. The process of globalization and internationalization belongs to the most important factors of international business development [14, 22].

Market globalization and production internationalization are the most significant features of the world economic development of the last decade. Globalization impacts have changed the rules of global competition radically. With the growth of market globalization, corporations and firms have found that they are strongly linked to foreign consumers [2], competitors and suppliers. Internationalization involves the expansion of global markets, institutions, certain norms and a process progressively reducing the purely domestic sphere of politics [18]. Internationalization deals with expansion across space and time. Researchers have framed internationalization as market growth and expansion through foreign direct investment (FDI) Competing space-time conceptions in consumers', authors' and societies' stories interact with managerial narratives [17] to affect international product and task environments [8]. Internationalization arises from entrepreneurial firms encompassing high levels of innovation and proactive policies [6]. The globalized competitive environment requires the firms to respond quickly to the consumers' needs and problems for which they should have adequate knowledge [9]. Employees' tasks always change according to the reengineering of the business processes. The management of changes, access requests, departing employees and other problems are usually not included in the strengths of today's companies [13].

\section{Theoretical View on the Regional Development in Relation to Foreign Direct Investments}

Joint ventures have expanded beyond the borders of national economies leading progressively, to the internationalization of entrepreneurship.

\begin{tabular}{|l|l|l|}
\hline Distinction & Activity & Level \\
\hline Trade & Export & Commercial \\
\hline Agreements & Licenses & Contractual \\
\hline Shareholding & Formation of consortia & Participatory \\
\hline Integration & Direct production investments & Integrating \\
\hline Autonomy & $\begin{array}{l}\text { Formation of the other firms in all } \\
\text { phases of the business activities }\end{array}$ & Autonomous \\
\hline
\end{tabular}

Figure 1

Motives of the internationalization of entrepreneurship 
Business internationalization presents an overrun in its business activities over the national boards. We considered these factors as basic factors influencing business internationalization:

- Opening of the national economies of individual countries

- Trends in national and international competition

- Sharply increasing expense on the research and development, shortening of the life cycle of the products and technologies (high level of the innovations)

- $\quad$ High capital requirement

- Improving of the transportation conditions and relative decrease of the transportation costs

- Development of the information and communication technology

- Enlargement and deepening of the services suitable for

- $\quad$ internationalization [19]

The most mentioned factor influencing business internationalization seems to be finance. Companies not expecting higher incomes in domestic markets, decide to transfer their business activity abroad. Motives of enterprises that have decided for internationalization of their business activities can be divided into two groups:

1) Proactive motives

2) Reactive motives (according to the activities of the individual enterprises).

Proactive motives are:

- $\quad$ Profit and growth of the company

- $\quad$ Initiative managers

- Unique product

- $\quad$ Potential foreign market

- $\quad$ Economies of scale

- $\quad$ Tax relief

Reactive motives are:

- Competitive pressure

- $\quad$ Limited size of the domestic market

- Overproduction

- Not initiated demand from abroad

- Expansion of the sale of seasonal products

- $\quad$ Proximity to foreign customers [4] 
The Slovak Republic can be characterized as a small open economy. This results not only in the fact that any development in the world is significantly reflected on the Slovak economic development but also in the fact that the Slovak economy is open to the movement of international capital in the form of investments (FDI) as well as in the form of portfolio investments (PFI).

The globalization phenomenon resulted in the strengthening of the movement of the international capital in the 1990s, which manifested in an intense inclusion of small open economies in the globalization process $[5,15]$.

The international movement of capital has the same base causes, as the capital movement, within the economy or economic group [3]. Attracting a foreign investor to capital manifestation in the Slovak market is not an easy task and requires the fulfillment of positive evaluations of six basic criteria; economic strength, entrepreneurial ethics, level of integration into the world economy, compliance with the law, investment climate and political stability. Another significant indicator of the economic stability considered by foreign investors is the relation between the current account deficit and the gross domestic product of the country. The foreign investor strives either for the domestic (local) market or a share on the world market. In the first case, exports are minimal and the foreign company competes only on the domestic market which probably results in the creation of a monopoly that has known disadvantages for the economy of the host country. In the second case, exports are maximum and the foreign company competes with other companies in the world market which leads to the company expanding the production and invests in new technologies and innovations which results in the higher quality of goods and services [11,23].

\section{Methodology and Data}

The goal of this paper is to identify the factors motivating Slovak companies for internationalization of their business activities and to recognize if Slovak corporations are motivated by the same factors for the internationalization of their business activities. Material used for the elaboration represent primary and secondary sources. Primary sources are the data gained by a questionnaire survey. The target group were the largest companies of the chosen industry in the Slovak Republic. These companies cover almost $80 \%$ of the all production in the chosen industry. The questionnaire was formed from the viewpoint of the company strategy, internationalization forms, sale of their products in foreign markets as the identification of reasons of their foreign business activities. The following hypothesis was determined by the elaboration of this paper: We assume that companies of chosen industry are motivated by the same factors by the internationalization of their business activities. 
We have defined ten factors influencing foreign business activities: business management interest in the territorial expansion, insufficient domestic demand, growing competitiveness in the domestic market, demand on the foreign market, an effort to build perspective foreign market position, the success of the competition in the foreign markets, acceptance of internationalization as a current trend in a globalizing world, company engagement in multinational network, working experience of the company's management in the international markets and the lack of subcontractors in the domestic market.

In reference to verify the qualitative signs of the development and present state of international business of the chosen industry in Slovakia, we used the $\chi 2$ test and the Friedman test. A chi-square test (1), also referred to as $\chi 2$ test is any statistical hypothesis test in which the sampling distribution of the test statistic is a chi-square distribution when the null hypothesis is true. Test criterion for verifying the null hypothesis $\mathrm{H}_{0}$ :

$\chi^{2}=\sum_{i=1}^{r} \sum_{j=1}^{c} \frac{\left(E_{i j}-T_{i j}\right)^{2}}{T_{i j}}$

As for small, sparse or unbalanced data, the exact and asymptotic $p$-values can be quite different and may lead to opposite conclusions concerning the hypothesis of interest, if appropriate, the Fisher test was used.

Friedman test (2) is nonparametric analogy of the two-factor analysis of variance with one observation in subclass. Input data are arranged into the matrix of $\mathrm{m}$ rows and $\mathrm{n}$ columns. Test statistic of the Friedman test:

$$
F=\frac{12 \times m}{n \times(n+1)} \times \sum_{j=1}^{n}\left[\sum_{i=1}^{m} T_{i j}-\frac{n+1}{2}\right]^{2}
$$

If the P-value is lower than chosen level of significance (usually 5\%=0.05), we reject the zero hypothesis. If the P- value is equal or higher than chosen level of significance, we cannot reject a zero hypothesis.

\section{Results}

More business enterprises lay stress on international opportunities, innovation activities and competitive advantages. From this viewpoint, their activities are affected by the factors and reasons regarding adaptation to the foreign market. At the present time, the process of internationalization and globalization is expressed by the group of strong entrepreneurial subjects which operate in the international environment and they represent competition for the domestic entrepreneurs [12, $20,22]$. 
The survey was conducted with a questionnaire during the period of August 2013 through December 2013. The target group were companies of a chosen industry that cover almost $80 \%$ of the all production in the chosen industry in Slovakia. The research sample consists of $62 \%$ companies with foreign investments and $38 \%$ companies without foreign investments. The development of business activities aims at achieving the basic motivation of all enterprises with effort how to entry the foreign market. A key element of the internationalization process concerns where and how a company chooses to do business outside its own country [19]. Figure 2 presents some forms of international activity of the searched companies.

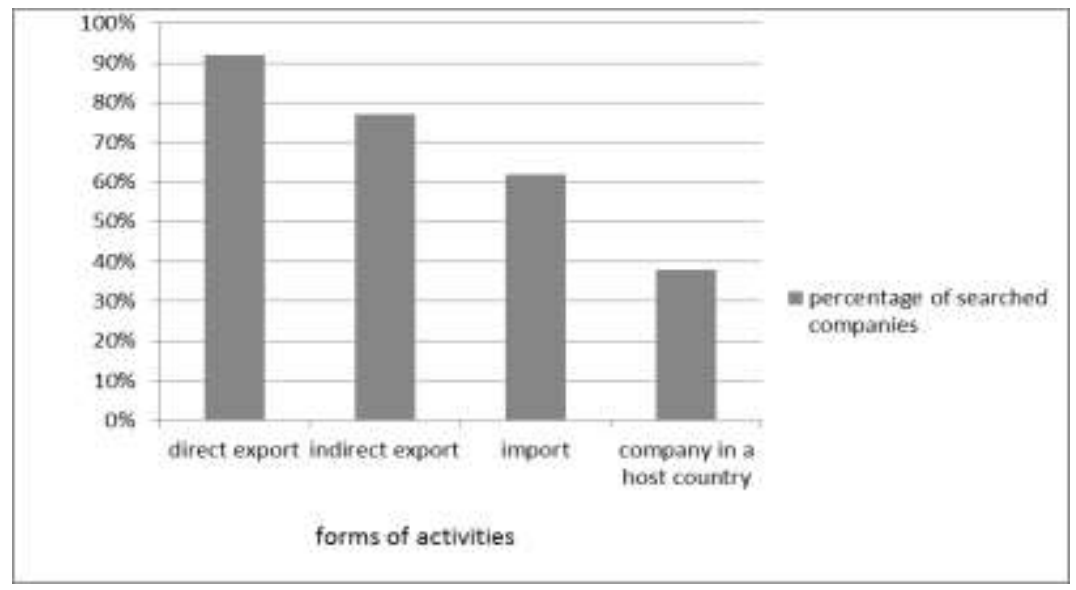

Figure 2

Forms of internationalization activities in the chosen companies in the Slovak Republic

By the internationalization process companies seek to increase the share in foreign markets. $85 \%$ of researched companies declared that their volume of sales in foreign markets increased during the searched period (years 2010-2013). 69\% of those companies sampled declared satisfaction with their foreign business activities. Furthermore, all companies stated that they operate in foreign markets regularly.

Factors indicating possible motives of operating on the international market clarify the issue of internationalization of the entrepreneurship. Research indicates that the main factors influencing our researched companies by internationalization of their business activities are management interest in territorial expansion, the success of the competition in the foreign markets and an effort to build perspective foreign market position. On the other hand, the less motivating factor by internationalization of their activities is the lack of subcontractors in the domestic market.

A firm's decisions, concerning the selection, entry and operation on the foreign market are related with the philosophy of business management oriented on the 
expansive goals and territorial expansion focused on the optimal goods and services location on the foreign markets. By an effort to gain expansive business goals, business management has to concern coincidence between internal sources and the business possibilities and external conditions influencing further enterprise development. $69 \%$ of all searched companies declared that business management interest in the territorial expansion was the factor with a significant impact on their operation in the foreign markets. In all, $8 \%$ of all enterprises defined this as a factor with a medium impact and the rest $23 \%$ of companies considered this factor as a factor with low or minimal impact on their foreign business activities.

$54 \%$ of all searched companies considered insufficient domestic demand as extremely important or very important by influencing their foreign business activities.

Trade liberalizing has influence the situation at the domestic markets. There are less domestic products of the chosen industry on the market in the Slovak republic. Particularly, opening markets and import have brought strong price competition and Slovak producers have not been prepared on it. $31 \%$ of all searched companies perceived impact of growing competitiveness in the domestic market as extreme by influencing their foreign business activities.

Demand on the foreign market represents significant factor by companies decisions about their operation at the foreign markets other hand. There were no companies that declared low or minimum impact of this factor on their business activities. $46 \%$ of all searched companies declared the high/extreme impact and $54 \%$ of them declared medium impact of existing demand on the foreign market on their own foreign business activities.

Perspective foreign market position is being built by companies by their firmness, long-term relations with foreign customers and by differentiation from competition by innovations. The improvement of business processes is a necessary part of innovations in business, aimed at improving of customer satisfaction and achieving more reliable productions. The above mentioned of steps are inevitable in today's world of high competitiveness and therefore the need for improvement of competitive abilities of an enterprise and its products grows steadily [5]. 77\% of all searched companies declared this effort as factor with an extreme or high impact on their foreign activities.

The success of the other companies is very motivating for the researched companies. $84 \%$ of companies declared extreme or high impact of the success of the competition in the foreign markets on their foreign business activities.

Adaptation of the business activities to the current situation in the market is characteristic for companies seeking success. $38 \%$ of all searched companies determined the impact of the process of internationalization on their business activities as high or extreme. 
Globalization and internationalization of entrepreneurship are closely related to multinational corporation. Most business entities consider the process of internationalization as an opportunity to develop innovative activities and to work on its competitive advantages. It is apparent that the network business brings many opportunities at innovations implementation for the entities involved. The environment is characterized by a competitive struggle. There is the importance of networks and networking as a means of increasing the competitiveness [16]. Our researched companies did not state significant impact of an effort to involve their company into the multinational corporation. Less than half $-46 \%$ of them declared that their business activities are influenced extremely by this factor. This may result from the fact that most of them have already been involved in multinational corporations or some other network cooperation.

Entering the new millennium, more and more organizations are trying to integrate into the global environment, and become aware of the need and importance of human resource management. Enterprises cannot be successful in the long term without people who possess the characteristics of entrepreneurs; also enterprises cannot be successful if individuals are entrepreneurial but the conditions within the enterprises are not established to promote entrepreneurship or even hinder the entrepreneurial actions of employees. Creativity, intuition, imagination, vision, carefulness, courage, honesty, patience, diligence, personal motivation and preparedness to work, persistence, dynamics, initiative, risk-propensity and sense for change, judgmental competences, firmness, decision-making abilities and preparedness for pioneer work are the essence of entrepreneurship [1, 9]. Managers of the searched companies had declared working experience before the companies started their foreign business activities. $62 \%$ of all researched companies considered this factor as a one with the high or extreme impact on their foreign business activities.

Working experience of the managers is an important factor that may significantly influence the initial phase of the internationalization process and also the complete success of the internationalization of the entrepreneurship.

Managers of the searched companies disposed different experiences and skills concerning foreign business activities. All searched companies declared that their managers had had experience from abroad, see Figure 1. $46 \%$ of searched companies stated that their managers had studied abroad. $85 \%$ of companies employed managers that had worked in other Slovak companies operating in foreign markets, $69 \%$ of companies employed managers that had worked for foreign companies before. $92 \%$ of all companies declared that their managers had contacts that allowed their company to enter the foreign market. 


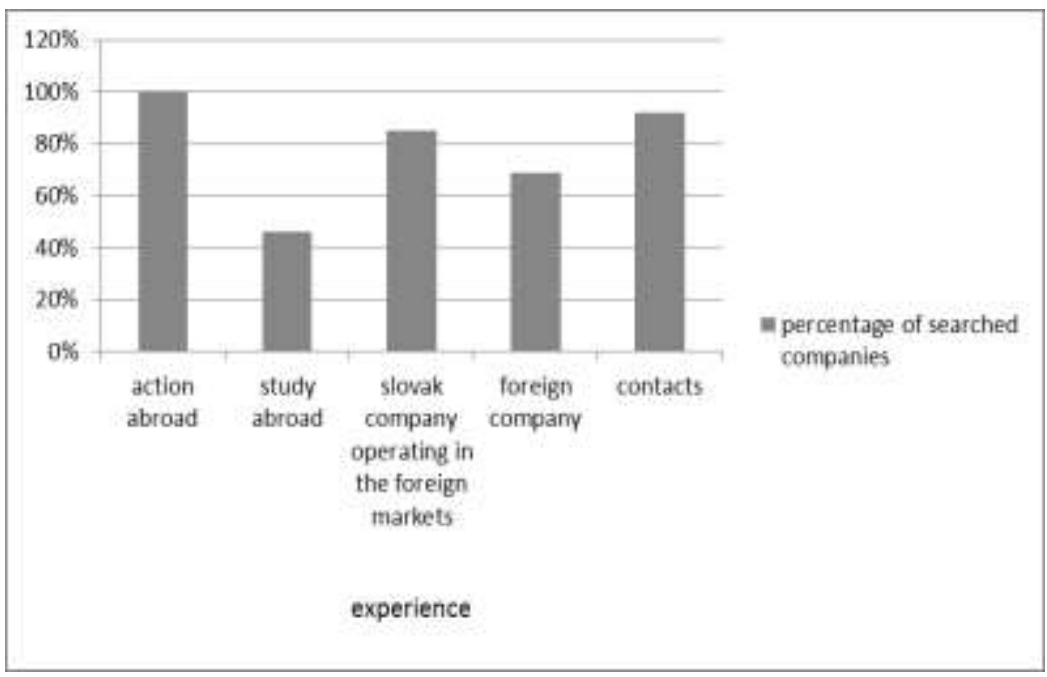

Figure 3

Working experience of the company's management in the foreign markets

Therefore, we tested if there is a correlation between foreign working experience of business management before starting foreign business activities and the sales volume. Our tested hypothesis:

$\mathrm{H}_{0}$ : individual foreign working experience of business management before starting foreign business activities and the sales volume in the foreign markets are independent.

$\mathrm{H}_{1}$ : individual foreign working experience of business management before starting foreign business activities and the sales volume in the foreign markets are dependent.

Table 4

Results of the calculation of the relationship between working experience in Slovak company operating at foreign markets before starting foreign business activities and the sales volume in the foreign markets by Chi- square test

\begin{tabular}{|c|c|c|c|c|c|}
\hline & Value & Df & $\mathbf{p}$ & $\begin{array}{c}\text { Exact Sig } \\
(\text { 2-sided })\end{array}$ & $\begin{array}{c}\text { Exact Sig. } \\
(\text { 1-sided })\end{array}$ \\
\hline Chi-square & 5.958 & 1 & 0.015 & & \\
\hline Fisher's Exact Test & & & & 0.154 & 0.154 \\
\hline
\end{tabular}

Based on results of the chi square test we reject the hypothesis $\mathrm{H}_{0}$ in the case of the working experience in Slovak company operating in the foreign markets and we adopt the hypothesis that there is a relationship between working experience in Slovak companies operating within foreign markets before starting foreign business activities and the sales volume in the foreign markets. By the other 
researched experience we do not reject $\mathrm{H}_{0}$ and we adopt the hypothesis that there is no relationship between individual foreign working experience of business management before starting foreign business activities - experience from action abroad, experience from study abroad, working experience from a foreign company, and contacts the sales volume in the foreign markets.

The lack of subcontractors in the domestic market seemed to be the factor at least influencing the researched companies with their decisions about their foreign business activities. $69 \%$ of all searched companies considered, this factor as a one with the low or minimum impact on their foreign business activities. $8 \%$ of companies perceived the medium impact of this factor and $23 \%$ perceived the high impact of this factor on their foreign business activities.

We tested using the Friedman test if in the researched sample of the answer on the single questions on factors motivating Slovak companies by the internationalization of their business activities and found differences only of random or statistically significance.

\begin{tabular}{|c|c|c|}
\hline \multicolumn{2}{|l|}{ Ranks } & \multirow{2}{*}{ Median } \\
\hline & $\begin{array}{l}\text { Average } \\
\text { Ranking }\end{array}$ & \\
\hline a) Business management interest in the territorial expansion & 4.62 & 1.0000 \\
\hline b) Insufficient domestic demand & 5.31 & 2.0000 \\
\hline c) Growing competitiveness in the domestic market & 5.96 & 3.0000 \\
\hline d) Demand on the foreign market & 4.92 & 3.0000 \\
\hline e) An effort to build perspective foreign market position & 4.04 & 1.0000 \\
\hline f) The success of the competition in the foreign markets & 5.46 & 3.0000 \\
\hline $\begin{array}{l}\text { g) Acceptance of internationalization as a current trend in a } \\
\text { globalizing world }\end{array}$ & 6.15 & 3.0000 \\
\hline h) Company engagement in multinational network & 6.15 & 3.0000 \\
\hline $\begin{array}{l}\text { i) Working experience of the company's management in the } \\
\text { international markets }\end{array}$ & 4.69 & 2.0000 \\
\hline j) The lack of subcontractors in the domestic market & 7.69 & 5.0000 \\
\hline
\end{tabular}


Table 5

Results of the calculation of the statistical significance of the differences among the among the individual factors that motivated Slovak companies by the internationalization of their business activities by Friedman test (made in SPSS).

Test Statistics

\begin{tabular}{|c|c|}
\hline $\mathrm{N}$ & 13 \\
\hline Chi-square & 16.055 \\
\hline $\mathrm{Df}$ & 9 \\
\hline $\mathrm{P}$ & 0.066 \\
\hline
\end{tabular}

\section{Our tested hypothesis:}

$\mathrm{H}_{0}$ : there is no statistically significant difference among the individual factors that motivated Slovak companies by the internationalization of their business activities. $\mathrm{H}_{1}$ : there is a statistically significant difference among the individual factors that motivated Slovak companies by the internationalization of their business activities.

Based on the results ( $\mathrm{p}=0.066$ ), see Table 5, we can accept hypothesis $\mathrm{H}_{0}-\mathrm{i}$. e. enterprises are motivated by factors among them that there is no statistically significant difference. We can state that researched companies are motivated by factors within the internationalization of the entrepreneurship.

\section{Conclusions}

Advancing globalization and internationalization processes are directly related to the injection of foreign capital into Slovak businesses and has forced management to review the realization of business activities. The foundation of the internationalization process is in the growing difficulty of the competitive environment of the market. All searched companies realize internationalization activities and they perform them regularly. The most realized activities are export and indirect export. No company realizes sale license as a form of internationalization of entrepreneurship. The sales volume abroad, has grown for almost all companies during the last 3 years. $69 \%$ of all companies are satisfied with their internationalization activities. We found that the most important factors influencing the internationalization of entrepreneurship in the studied companies are management interest in territorial expansion, the success of the competition in the foreign markets and an effort to build perspective market position abroad. The less important factor seems to be the lack of subcontractors in the domestic market. We have an accepted hypothesis that companies perceive single factors similarly, so they are motivated by the same factors for the internationalization of their business activities. Managers of the studied companies have different 
experiences from their operations abroad. $100 \%$ of studied companies have declared that their managers have job experience from abroad. On the other hand, only $46 \%$ of managers have study experience from abroad. We have accepted the hypothesis that there is a relationship only between job experience from domestic firms operating abroad and sales volume abroad.

\section{Acknowledgement}

Supported by the Scientific Grant Agency of the Ministry of Education: VEGA No. 1/0381/13 on the topic: "Evaluation of the innovative potential of entrepreneurial networks in the early stages of its functioning"; Project KEGA No. 032PU-4/2013 on the topic: "E-learning application by training of the economic subjects of the study program Management and new accredited study programs at the Faculty of Management University of Prešov in Prešov".

\section{References}

[1] Belak, J. and Duh, M. (2012): Integral Management: Key Success Factors in the MER Model. Acta Polytechnica Humgarica, 9 (3): 5-26

[2] Buleca, J., Raisová, M., Michalski, G. (2014): Food Processing Firms Inventory Levels in Hard Times. 2004-2012 Slovak, Czech and Polish Enterprises Case. Procedia Economics and Finance (12): 557-564

[3] Buleca, J. (2013): Support for Innovation and Entrepreneurship in Region of Košice. Acta Oeconomica Universitatis Selye, 2 (2): 47-54

[4] Chovancová, J. and Huttmanová, M. (2014): Possibilities of Expatriates` Preparation for International Tasks and Analysis of Factors of Their Success. Proceedings of the International Scientific Conference on MMK 2014, Magnanimitas, Hradec Králove, pp. 52-57

[5] Demel, J. and Potužáková, Z. (2012): FDI and the Liberec Region: the Case of the Labour Market. E\&M Economics and Management Journal, 4: 4-18

[6] Glavas Ch., Mathews, S. (2014): How International Entrepreneurship Characteristics Influence Internet Capabilities for the International Business Processes of the Firm. International Business Review, 23 (1): 228-245

[7] Hajdu et al. (2014): Utilizing Experiments Designed Results during Error Identification and Improvement of Business Processes. Acta Polytechnica Hungarica, 11 (2): 149-166

[8] Haley, U. C. V. and Boje, D. M. (2014): Storytelling the Internationalization of the Multinational Enterprise. Journal of International Business Studies, 45 (9): 1115-1132

[9] Hron J. (2006): Knowledge and Strategic Management. Agricultural Economics - Czech, 52 (3): 101-106

[10] Hollensen, S. (2011): Global Marketing, Harlow, ISBN 978-0-273-72622-7 
[11] Kadeřábková, B. (2000): Economic Growth and Foreign Direct Investment. In: Hudakova M (Ed.): Zborník vedeckých prác z medzinárodnej vedeckej konferencie 2000. SPU, Nitra: 315-323

[12] Katič, et al. Modelling the Composite Competitiveness Index of the Knowledge-based Society. Acta Polytechnica Hungarica Vol. 12, No. 1, 2015, pp. 229-249

[13] Keszthelyi, A. and Michelberger, P. (2012): From the IT Authorisation to the Role- nad Identity Management. $4^{\text {th }}$ IEEE International Symposium on Logistics and Industrial Informatics (LINDI) pp. 173-177

[14] Machková H. (2006): Mezinárodní marketing (International Marketing). Grada Publishing, Praha; ISBN 80-247-1678-X

[15] Matejková, E., Qineti, A. and Serenčéš, R. (2008): Macroeconomic Aspects of the Development of Slovak Regions in the Post-Accession Period. Agricultural Economics - Czech, 2008, 54(8): 367-375

[16] Mura L. and Rózsa, Z. (2013): The Impact of Networking on the Innovation Performance of SMEs. $7^{\text {th }}$ International Days of Statistics and Economics Location: Prague, pp. 1036-1042

[17] Poór, J. et al. HR Management at Subsidiaries of Multinational Companies in CEE in Light of Two Surveys of Empirical Research in 2008 and 2013. Acta Polytechnica Hungarica Vol. 12, No. 3, 2015, pp. 229-249

[18] Solingen. E. (2015): Mapping Internationalization Domestic and Regional Impacts. Comparative Regionalism: Economics and Security: 91-116

[19] Sršňová, J. and Füzyová, L. (2003): International Strategic Business Decision. Bratislava: Sprint, ISBN 80-89085-18-0

[20] Szabo, K. Zs. and Herman, E. Productive Entrepreneurship in the EU and Its Barriers in Transition Economies: A Cluster Analysis. Acta Polytechnica Hungarica Vol. 11, No. 6, 2014, pp. 73-94

[21] Ubrežiová, I. et al. (2005): International Management and Entrepreneurship. Nitra: SPU, 2005, ISBN 80-8069-619-5

[22] Ubrežiová I. et al. (2009): International Business and the Reasons of the Internationalization Activities in the Slovak Agri-Food Complex: The Case Study of the Slovak Milk Processing Industry. Agricultural Economics, 55, 2009 (12): 605-610

[23] Zamrazilová, E. (2007): Foreign Direct Investments in the Czech Republic: Selected Macroeconomic Issues. Politická ekonomie, 5: 579-602 